Muller, S. W. comp. 1947. Permafrost, or permanently frozen ground, and related engineering problems. Ann Arbor, J. W. Edwards, Inc.

Popov, A. I., and others. 1966. Features of the development of frozen geomorphology in northern Eurasia, by A. I. Popov, S. P. Kachurin and N. A. Grave. (In U.S. National Research Council. Building Research Advisory Board. Proceedings of an international conference on permafrost. Washington, D.C., p. I8I-85. ([U.S.] National Academy of Sciences-National Research Council Publication 1287.))

Porsild, A. E. 1938. Earth mounds in unglaciated Arctic northwestern America. Geographical Review, Vol. 28, No. I, p. 46-58.

No. I, P. 46-58.
Shumskiy, P. A. I959. Podzemnyye l'dy [Ground (subsurface) ice]. (In Tsytovich, N. A., ed. Osnovy geokriologii (merzlotovedeniya). Chast' pervaya [Principles of geocryology (permafrost studies). Part I]. Moscow, Izdatel'stvo Akademii Nauk SSSR [Publishing House of the Academy of Sciences of the U.S.S.R.], p. 274-327.) [English translation: Canada. National Research Council. Technical Translation I I 30, 1964.]

Shumskiy, P. A., and Vtyurin, B. I. 1966. Underground ice. (In U.S. National Research Council. Building Research Advisory Board. Proceedings of an international conference on permafrost. Washington, D.C., p. I08-13. ([U.S.] National Academy of Sciences-National Research Council Publication 1287.))

Stearns, S. R. 1966. Permafrost. U.S. Cold Regions Research and Engineering Laboratory. Cold regions science and engineering. Hanover, N.H., Pt. I, Sect. I-A2.

Terzaghi, K. 1952. Permafrost. Fournal of the Boston Society of Civil Engineers, Vol. 39, No. 1, p. 1-50.

Werenskiold, W. 1953. The extent of frozen ground under the sea bottom and glacier beds. Journal of Glaciology, Vol. 2, No. 13, p. 197-200.

\title{
SIR, Comments on "The formation of shear moraines: an example from south Victoria Land, Antarctica"
}

I was most interested in the article by Souchez ( 1967$)$ as I have spent some time studying the socalled "shear moraines" near Thule in north-west Greenland. My experience in Greenland leads me to wonder about some of the observations of Souchez and to question some of his conclusions.

First, Souchez mentions upwarping of flow lines (foliation planes?) near the glacier margin. I would be interested to know what causes this upwarping. In Greenland, a similar effect can be observed where active glacial ice tends to over-ride stagnant ice in wind-drift ice wedges (Fig. I). The ice wedges are so thin that they deform very slowly if at all. More rapidly flowing glacial ice is forced upward by the stagnant wedges and foliation beneath the moraines thus dips steeply up-glacier. The boundary between active ice and ice in the wind-drift wedges is probably marked by a rapid (but not discontinuous) decrease in shear strain downward as indicated schematically by the velocity profile in Figure $\mathrm{I}$.

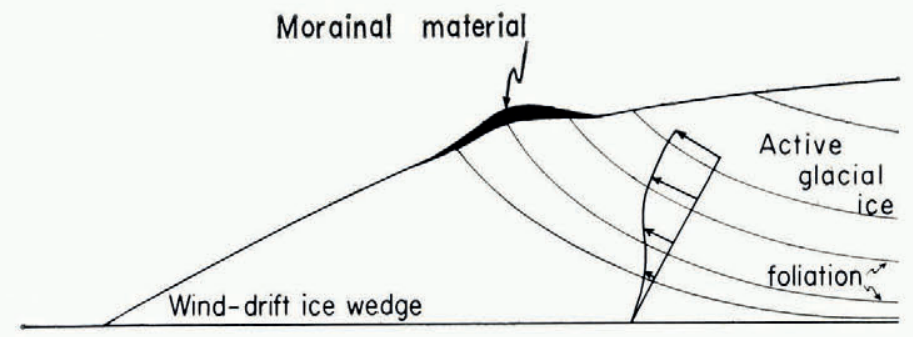

Fig. 1. Schematic cross-section of the edge of the Greenland ice sheet near Thule. Morainal material is incorporated into the ice at the base of the glacier and is released at the surface by ablation. Insulation causes morainal deposits to stand above nearby debrisfree glacial ice. Debris in the ice is concentrated in bands which constitute foliation bands and which parallel foliation bands defined by differences in bubble content and by other characteristics of the ice alone

Wind-drift wedges have a higher winter accumulation than nearby glacial ice because the wedges are in the lee of moraines and drifting snow blown off the ice sheet accumulates on them. This enables wind-drift wedges to maintain themselves without replenishment by flow of ice from the interior of the ice sheet. It is not clear whether the stagnant ice mentioned by Souchez plays the same role in Antarctica.

Secondly, the debris-containing fault planes described by Souchez are not found in Greenland. Solid dirt bands (with only interstitial ice) are found but these generally parallel nearby foliation that dips up-glacier. These debris bands contain all sizes of material and a few retain evidence of fluvial stratification. Such stratification would probably not be preserved if the blocks were "sheared" into the ice.

Souchez says that his fault planes are parallel to thermal contraction fissures found farther back on the glacier. Because there is morainal material on the ice surface in the area where these cracks develop, 
it seems pertinent to ask if the debris in the fault planes may not represent crevasse fillings. This would explain the absence of fine material in the fillings, as fines are frequently winnowed out of morainal material that has been on the ice surface for some time.

It should also be noted that the fault planes shown in Souchez' figure 3 have dips that are rather steep to be accounted for by normal shear deformation, and that offset of the foliation, as shown, is in the wrong direction to be attributed to such shear. Interpreting these features as crevasse fillings might be more consistent with the observations at hand.

Finally, Weertman's objection to the shear hypothesis is based on the fact that fault-type shear displacements across infinitely thin planes $(\mathrm{d} V / \mathrm{d} y \rightarrow \infty)$ probably do not occur commonly in ice under high hydrostatic pressure as at the base of an ice sheet. Plastic deformation with finite shear strain ( $\mathrm{d} V / \mathrm{d} y$ finite) is probably the normal mode of flow. Used in this latter sense, the term "shear moraine" is valid. However Bishop (1957, p. 17) refers to debris being carried to the surface along "high-angle imbricate shears". This implies a fracture or fault type of displacement and the term shear moraine thus has a very explicit genetic connotation. For this reason it seems desirable to abandon the term. I have used the name "ice-perched moraine" in my Greenland work.

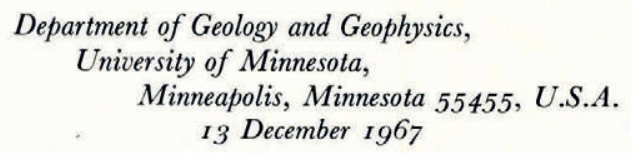

Roger LeB. HoOKe

\section{REFERENCES}

Bishop, B. C. 1957. Shear moraines in the Thule area, northwest Greenland. U.S. Snow, Ice and Permafrost Research Establishment. Research Report i 7.

Souchez, R. A. 1967. The formation of shear moraines: an example from south Victoria Land, Antarctica. Fournal of Glaciology, Vol. 6, No. 48, p. 837-43.

\section{SIR, Reply to Dr R. LeB. Hooke's comments on "The formation of shear moraines: an example from south Victoria Land, Antarctica"}

In his comments on my paper (Souchez, 1967 ), Hooke poses three questions: the first is merely for information about the causes of upwarping and the possible occurrence of a wind-drift ice wedge; the second deals with an alternative explanation of the localized fault planes filled with debris and considered as crevasse fillings; and the last is a problem of terminology about the well-known term "shear moraine".

First, in contrast to the north-west Greenland situation described by Hooke, the role of wind-drift ice wedges is, to my mind, not applicable in the case studied. In the Upper Ferrar Glacier area, at an altitude of $\mathrm{r} 800 \mathrm{~m}$, melting is exceptional and only localized near rock outcrops. Superimposed ice is not significant. Ice formation is a very slow process which occurs mainly by pressure of the overlying snow without the participation of surface melt water. This reduces the possibility of wind-drift ice wedges in this area. On the other hand, if we refer to figure 2 of my paper (Souchez, 1967) and if we assume that the first (northern) and oldest morainic ridge in region "C" was formed at the boundary between glacier ice and a wind-drift ice wedge, it is difficult to explain in a similar manner the second ridge, and the third which is even less developed. Everywhere between the ridges there is the same blue dense ice which is characteristic of Upper Ferrar Glacier. It should also be noted that the ridges in region "C" are not parallel to the boundary and that, when it is not masked by debris, the base of the ice shows foliation bands, dirt bands and debris bands dipping up-glacier, a situation not easily explained by a wind-drift ice wedge. That wind-drift ice wedges may play an important role in the genesis of some socalled "shear moraines" is very probable. Østrem (1964) has emphasized the role of old snow banks in the formation of ice-cored moraines in Scandinavia. But we must also take into account, in other cases, that upwarping may be caused by a stagnant wedge of glacier ice having slow plastic deformation and no basal sliding, because of the presence of permafrost beneath the glacier which extends inwards some distance from its edge. Finally, because of my participation in a programme on southern Ellesmere Island with the Geological Survey of Canada, I saw so-called "shear moraines" not too far from Thule. Even there, the upwarping cannot always be attributed to the process mentioned by Hooke. Some 